Review Article

\title{
Health Promoting Effects of Brassica-Derived Phytochemicals: From Chemopreventive and Anti-Inflammatory Activities to Epigenetic Regulation
}

\author{
Anika Eva Wagner, Anna Maria Terschluesen, and Gerald Rimbach \\ Institute of Human Nutrition and Food Science, Christian-Albrechts-University Kiel, Hermann-Rodewald-Straße 6, \\ 24118 Kiel, Germany \\ Correspondence should be addressed to Anika Eva Wagner; wagner@molecularnutrition.uni-kiel.de
}

Received 10 October 2013; Accepted 20 November 2013

Academic Editor: José Luís García-Giménez

Copyright (C) 2013 Anika Eva Wagner et al. This is an open access article distributed under the Creative Commons Attribution License, which permits unrestricted use, distribution, and reproduction in any medium, provided the original work is properly cited.

A high intake of brassica vegetables may be associated with a decreased chronic disease risk. Health promoting effects of Brassicaceae have been partly attributed to glucosinolates and in particular to their hydrolyzation products including isothiocyanates. In vitro and in vivo studies suggest a chemopreventive activity of isothiocyanates through the redox-sensitive transcription factor Nrf2. Furthermore, studies in cultured cells, in laboratory rodents, and also in humans support an antiinflammatory effect of brassica-derived phytochemicals. However, the underlying mechanisms of how these compounds mediate their health promoting effects are yet not fully understood. Recent findings suggest that brassica-derived compounds are regulators of epigenetic mechanisms. It has been shown that isothiocyanates may inhibit histone deacetylase transferases and DNAmethyltransferases in cultured cells. Only a few papers have dealt with the effect of brassica-derived compounds on epigenetic mechanisms in laboratory animals, whereas data in humans are currently lacking. The present review aims to summarize the current knowledge regarding the biological activities of brassica-derived phytochemicals regarding chemopreventive, anti-inflammatory, and epigenetic pathways.

\section{Introduction}

Epidemiological studies link a high intake of brassica vegetables with a lower incidence for different kinds of cancers [1-3]. Health promoting effects of brassica vegetables have been attributed to glucosinolates, sulfur containing compounds almost exclusively present in plants of the family Brassicaceae. However, these chemopreventive effects are not mediated by glucosinolates per se but mainly through isothiocyanates, one of the major hydrolysis products resulting from myrosinase cleavage [4-9]. Myrosinase is a thioglucohydrolase located apart from glucosinolates in so-called myrosin cells. Upon plant cell disruption enzyme and glucosinolate get in contact and hydrolization is initiated. Based on reaction conditions (e.g., $\mathrm{pH}$, temperature) either isothiocyanates, thiocyanates, or nitriles are formed (Figure 1) [10, 11].
Several in vitro and in vivo studies suggest that brassica derived phytochemicals may counteract inflammatory pathways and exhibit chemopreventive activity. Furthermore, impact of glucosinolates and/or their corresponding hydrolyzation products on epigenetic mechanisms including DNA-methylation, histone modification, and microRNAs has been recently described and is in the focus of the present paper. Chemical structures of selected brassica-derived phytochemicals are presented in Figure 2.

\section{Brassica-Derived Phytochemicals Target Inflammatory Pathways}

Several studies suggest anti-inflammatory properties of brassica-derived phytochemicals [12]. Besides others, these beneficial effects may be mediated through an induction of 

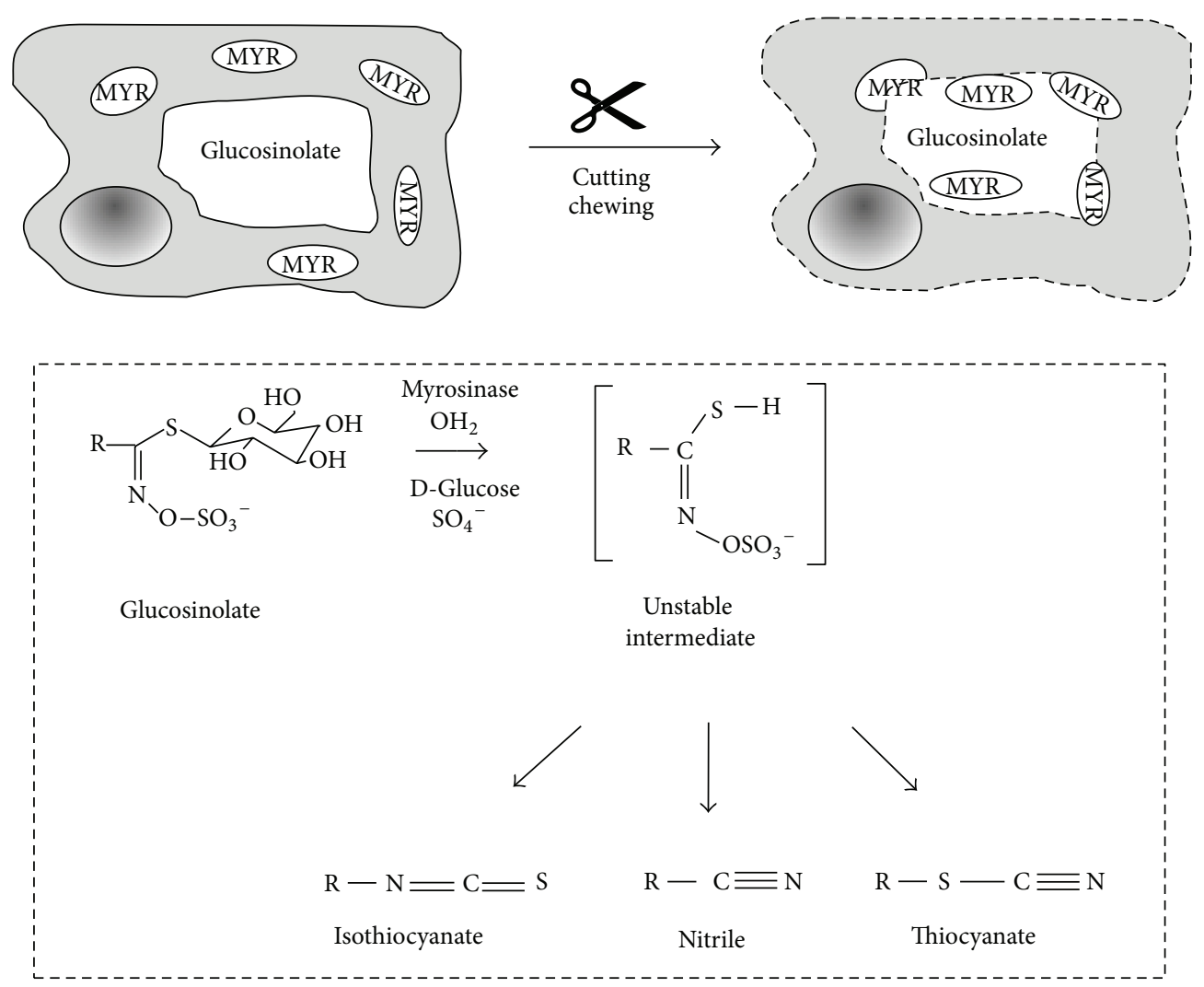

FIGURE 1: Myrosinase-mediated hydrolysis of glucosinolates with main break-down products (modified according to [114]).<smiles>CS(=O)CCCCN=C=S</smiles>

Sulforaphane

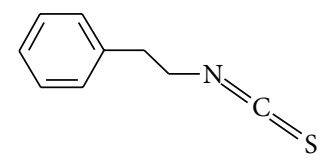

Phenylethyl-isothiocyanate<smiles>C=CCN=C=S</smiles>

Allyl-isothiocyanate<smiles>OCc1c[nH]c2ccccc12</smiles>

Indole-3-carbinol<smiles>CCCCN=C=S</smiles>

Butyl-isothiocyanate<smiles>c1ccc2c(Cc3c[nH]c4ccccc34)c[nH]c2c1</smiles>

$3,3^{\prime}$-Diindolylmethane<smiles>S=C=C=NCCCCCCc1ccccc1</smiles>

Phenylhexyl-isothiocyanate<smiles>CS(=O)CCCN=C=S</smiles>

Iberin<smiles>S=C=NCc1ccccc1</smiles>

Benzyl-isothiocyanate

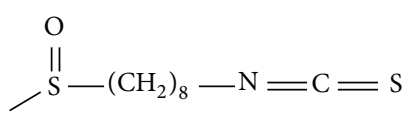

8-Methylsulfonyloctyl isothiocyanate

FIGURE 2: Chemical structures of selected aliphatic and aromatic brassica-derived phytochemicals. 
antioxidant and phase $1 / 2$ genes and the inhibition of proinflammatory signaling pathways via regulation of various transcription factors which may be further controlled by epigenetic modifications and miRNAs [11, 13-15]. Additionally, it has been shown that brassica derived phytochemicals exhibit anti-infective and antiviral activity (e.g. inhibiting Helicobacter pylori) [16-18]. In this context the transcription factor nuclear factor kappa $\mathrm{B}(\mathrm{NF} \kappa \mathrm{B})$ is a central player in inflammatory processes. In general, $\mathrm{NF} \kappa \mathrm{B}$ resides inactively in the cytosol as a heterodimer consisting of two subunits, for example, p50 and p65, bound to its inhibitory protein $\mathrm{I} \kappa \mathrm{B} \alpha$ [19]. NF $\kappa \mathrm{B}$ can be activated by a wide variety of proinflammatory stimuli including cytokines and reactive oxygen species resulting in the activation of upstream kinases, phosphorylation, ubiquitination, and consequently the degradation of $\mathrm{I} \kappa \mathrm{B} \alpha[20]$. Once p50 and p 65 have been released, they translocate to the nucleus and bind to the $\kappa \mathrm{B}$ site located in the promoter regions of the DNA of target genes thereby driving gene expression $[21,22]$. $\mathrm{NF} \kappa \mathrm{B}$ target genes include, for example, cyclooxygenase 2 (COX-2), inducible nitric oxide synthase (iNOS) (inflammatory function), Bcl-Xl, Bcl-2, Bcl-3 (anti-apoptotic function), MYC (cell division), matrix metalloproteinase (MMP), and vascular endothelial growth factor (VEGF) (angiogenesis) [23-25]. Due to NF $\kappa$ Bs central role in inflammation the transcription factor seems to be an attractive target to treat inflammation related diseases.

A variety of naturally occurring $N F \kappa B$ inhibitors have been described including brassica derived phytochemicals like sulforaphane (SFN), phenethyl-isothiocyanate (PEITC), 8-methylsulphinyloctyl isothiocyanate (MSO), and indole3-carbinol (I3C). They downregulate lipopolysaccharide (LPS) induced activation of $\mathrm{NF} \kappa \mathrm{B}$ and suppress COX2, iNOS, and prostaglandin (PG) expression in cultured mouse macrophages, possibly via inactivating $\mathrm{NF} \kappa \mathrm{B}[26-$ 31]. Furthermore, $3,3^{\prime}$-diindolylmethane (DIM) significantly reduced PGE(2), NO, proinflammatory cytokines, and the number of colon tumors in $\mathrm{BALB} / \mathrm{c}$ mice suffering from colitis associated colon cancer [32]. In C57BL/6 mice we observed that a 7-day pretreatment with SFN resulted in less severe symptoms of DSS-induced colitis as compared to PBS-pretreated controls [33]. Interestingly, Prawan et al. (2009) have observed that synthetic ITCs show an even stronger anti-inflammatory activity than that of their natural counterparts [30]. However, the underlying mechanisms of how brassica derived phytochemicals modulate the NF $\kappa \mathrm{B}$ pathway are only partly understood. Most studies indicate that ITCs inhibit DNA binding of NF $\kappa$ B, suppress its translocation, or stabilize $\mathrm{I} \kappa \mathrm{B} \alpha$ through a decreased phosphorylation of I $\kappa$ B kinase complexes (IKKs) [26, 30, 34-36]. This in turn suggests that ITCs target upstream factors like MAPK pathways (e.g., ERK, JNK, or p38) resulting in $\mathrm{NF} \kappa \mathrm{B}$ inhibition [30]. A study conducted by Yang and coworkers (2010) confirmed this hypothesis by demonstrating that PEITC inhibits ERK1/2, MAPK kinase 7 (MAPKK7), and MAPK kinase kinase 3 (MAPKK3) [37]. ITCs may also act anti-inflammatorily through lowering ROS-induced $\mathrm{NF} \kappa \mathrm{B}$ activity [34]. Heiss and coworkers observed that SFN impairs DNA-binding of $\mathrm{NF} \kappa \mathrm{B}$ which was not accompanied by $\mathrm{I} \kappa \mathrm{B}$ degradation and nuclear translocation of $\mathrm{NF} \kappa \mathrm{B}$ [26]. It is supposed that SFN interacts with thiol groups, forms dithiocarbamates, and binds directly to redox-regulated cystein residues (Cys62 and Cys38) of the p50 and p65 subunits which prevent DNA binding [38]. A modification of these cystein residues may provide an alternative strategy for phytochemical mediated chemoprevention [20]. Brassica derived phytochemicals may also mediate anti-inflammatory effects through an interaction with reduced redox regulators like glutathione, thioredoxin, or redox factor 1 (ref-1), leading to changes of the reducing milieu required for correct DNA binding [39].

\section{Brassica-Derived Phytochemicals Target Chemopreventive Pathways}

Nrf2 is a transcription factor playing a crucial role in regulating inflammation and chemoprevention. Under basal conditions Nrf2 is bound to its cytosolic inhibitor, the Kelch like ECH-associated protein 1 (Keapl) [40]. In the presence of activating agents including isothiocyanates and other electrophiles Nrf2 may be activated through two distinct cellular signaling pathways resulting in the liberation of Nrf2 from its inhibitor Keap1. Nrf2 can either be phosphorylated through an activation of upstream protein kinases which causes the destruction of the Nrf2-Keapl complex or in the presence of pro-oxidants the cysteine thiols of Keapl may be modified which promotes dissociation of Nrf2 from Keap1. Liberated Nrf2 translocates to the nucleus where it binds together with several cofactors including small Maf proteins (MafF, MafG, and MafK), c-Jun, and cAMP response element-binding (CREB) protein (CBP) to the antioxidant response elements (AREs) in the promoter regions of genes encoding antioxidant and detoxifying phase II enzymes like NADPH quinone oxidoreductase 1 (NQO1), hemeoxygenase1 (HO-1), superoxide dismutase (SOD), glutamyl cysteine ligase (GCL), and GST [20, 41]. Khor et al. (2006) have reported that Nrf2-deficient mice suffer under a more severe dextran-sulfate-sodium- (DSS-)induced colitis than Nrf2+ mice which was accompanied by a decreased expression of antioxidant and phase II enzymes and an increased level of proinflammatory mediators like COX-2, iNOS, interleukin $1 \beta$ (IL-1 $\beta$ ), and tumor necrosis factor $\alpha(\mathrm{TNF} \alpha)$ [42]. Different phytochemicals can lead to nuclear accumulation of Nrf2 [43, 44]. In particular, the effect of SFN on Nrf2 pathways has been intensively investigated, showing that SFN in vitro and in animal studies successfully activates phase 2 and antioxidant enzymes via induction of Nrf2 [45-48]. Also other ITCs such as allyl-isothiocyanate (AITC), butyl-isothiocyanate (BITC), and PEITC have been shown to exhibit similar Nrf2 inducing activity in vitro $[48,49]$. PEITC has been proven to be an even stronger inducer of Nrf2-ARE mediated signaling pathways than SFN [50].

There is evidence that overexpression of Nrf2 can modulate $\mathrm{NF} \kappa \mathrm{B}$ expression, since $\mathrm{NF} \kappa \mathrm{B}$ competes with $\mathrm{Nrf} 2$ for binding to the transcriptional coactivator CREB-binding protein $[51,52]$. Accordingly, Surh and Na described a crosstalk between $\mathrm{NF} \kappa \mathrm{B}$ and $\mathrm{Nrf2}$ signaling supported by the fact that most of the phytochemicals exhibit both, antiinflammatory and anti-oxidant properties [20]. 


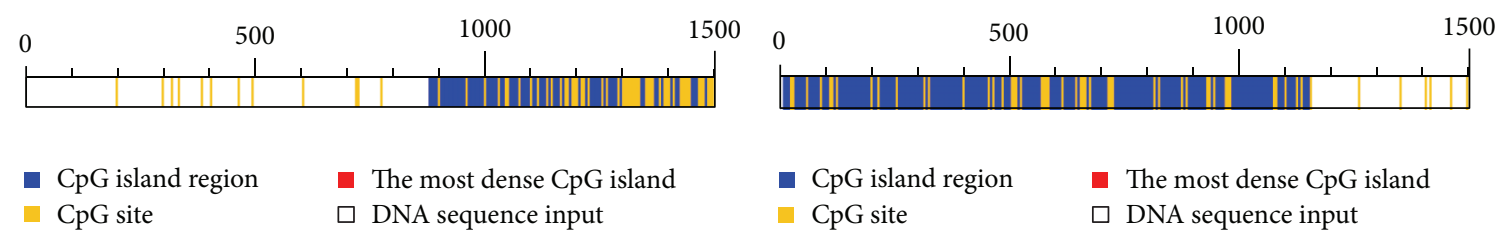

(a)

(b)

FIgURE 3: CpG islands in the promoter of Nrf2 (a) and Keap1 (b) identified by using the database dbcat (http://dbcat.cgm.ntu.edu.tw/).

\section{Brassica Derived Phytochemicals Target Epigenetic Pathways}

Epigenetics describe a heritable change in gene expression that is not mediated through a change of DNA-sequence [53]. Epigenetic changes comprise DNA-methylation, histone modifications, and microRNA expressions [53-55]. Several studies suggest that brassica derived phytochemicals affect epigenetic mechanisms. Epigenetic aberrations take place in the early stages of carcinogenesis and partly represent an initiating process of cancer development. Phytochemicals may intervene in this process and incarnate potential targets for cancer prevention [56]. Posttranslational modifications at the $\mathrm{N}$-terminal tail of histones are one epigenetic mechanism that plays a role in gene regulation and carcinogenesis [56, 57]. Histones can be post-translationally modified by acetylation, deacetylation, phosphorylation, ubiquitinylation, sumoylation, and ADP ribosylation [58, 59]. Biotinylation has also been suggested to mediate histone modification. However, recent studies conducted by $\mathrm{Li}$ and coworkers as well as by Xue and colleagues discovered that it is not a biotinylation per se but an assembly of different proteins including biotin ligase and holocarboxylase synthetase interceding histone modification $[60,61]$. Histone acetylation and deacetylation are the most analysed modifications mediated through a coaction of histone acetyl transferases (HAT) and histone deacetylases (HDAC) [56] resulting in gene activation and inhibition of gene activity, respectively [57, 62]. HATs transfer acetyl groups from acetyl-CoA onto lysine residues at the histone [63] while HDACs detach histone acetyl group transferring them onto CoA [56]. Chromatin acetylation by HATs opens the chromatin structure providing a possibility for transcription factors to approach the DNA which may lead to gene activation [57]. HATs are divided into four families on the basis of their structure homologues. At present, however, there is no literature data available presenting effects of brassica derived phytochemicals on HAT activity. Several studies suggest an effect of these phytochemicals on HDACs. HDACs are also divided into four groups according to their structure homology to yeast deacetylases $[64,65]$. Both, in vitro and in vivo studies present ITCs as potent HDAC inhibitors [66]. Recent investigations by Rajendran and coworkers $[67,68]$ revealed a dose-dependent inhibition of HDAC activity and an increase of HDAC protein turnover following ITC incubation of HCT116 colon cancer cells that was proportionally dependent on their alkyl chain length. Besides colon cancer cells, HDAC inhibitory effects of SFN have been shown in various prostate epithelial cells-normal prostate epithelial cells (PrEC), benign hyperplasia (BPH1), and cancerous (LnCaP, PC-3) prostate epithelial cells $[69,70]$ as well as in different breast cancer cells [71]. The HDAC inhibitory effect of SFN has also been confirmed in an in vivo model [72, 73]. Also other ITCs, including PEITC [74], the synthetic phenylhexyl-ITC (PHI) [75-77] and benzylITC (BITC) [78], inhibit HDAC activity in different cell lines. The indole DIM, a known brassica derived plant bioactive, has been reported to decrease HDAC activity in the prostate cancer cell lines PC-3 and LnCaP. Interestingly, the monomer of the compound I3C had only a weak effect on LnCaP cells, which are androgen sensitive, and non on PC-3 cells being androgen-insensitive [79]. In a clinical trial it turned out that SFN-rich broccoli sprouts consumed by healthy human subjects exhibit HDAC inhibitory effects [73, 80].

DNA methylation is regulated by various DNAmethyltransferases (DNMT 1, 3a, 3b) that transfer methyl groups from the methyl precursor S-adenosyl-L-methionine (SAM) to the C5-position of certain cytosines and influence gene transcription [81, 82]. Gene promoter regions rich in $\mathrm{CpG}$ sequences-so called $\mathrm{CpG}$ islands-are generally unmethylated in normal cells [56], whereas transformed cells often show hypermethylated promoters and/or genome wide hypomethylation [57]. Predicted CpG islands in the promoters of Nrf2 and Keap1 are shown in Figure 3. Besides carcinogenesis changes in DNA methylation patterns are also associated with ageing and the development of chronic degenerative diseases $[56,83]$. Currently only little information regarding DNMT inhibition by ITCs is available in the literature. The main investigated ITC regarding its DNMT inhibiting activity is SFN. Studies conducted by Meeran and colleagues [84] in the human breast cancer cell lines, MCF-7 and MDA-MB-231, revealed an inhibiting effect of SFN on DNMT1 and DNMT3a. SFN has been reported to inhibit DNMT-expression in the human colorectal cancer cell line CaCo-2 [85], in LnCaP human prostate cancer cells [86], and in porcine satellite cells [87]. Furthermore, effects of the naturally occuring ITC iberin [85] and the synthetic ITC PHI on DNMT inhibition in colorectal cancer cells and in the acute lymphoid leukemia cell line Molt-4 [88] have been described. However, in vivo data for DNMT inhibition by brassica derived phytochemicals is lacking and needs further investigation.

MicroRNAs (miRNA) represent a class of evolutionary conserved small noncoding RNAs with a length of $\sim 22$ nucleotides that control gene expression at the posttranscriptional level [89-91]. MicroRNAs bind to the $3^{\prime}$ untranslated region ( $\left.3^{\prime} \mathrm{UTR}\right)$ of target mRNAs and lead, depending on 


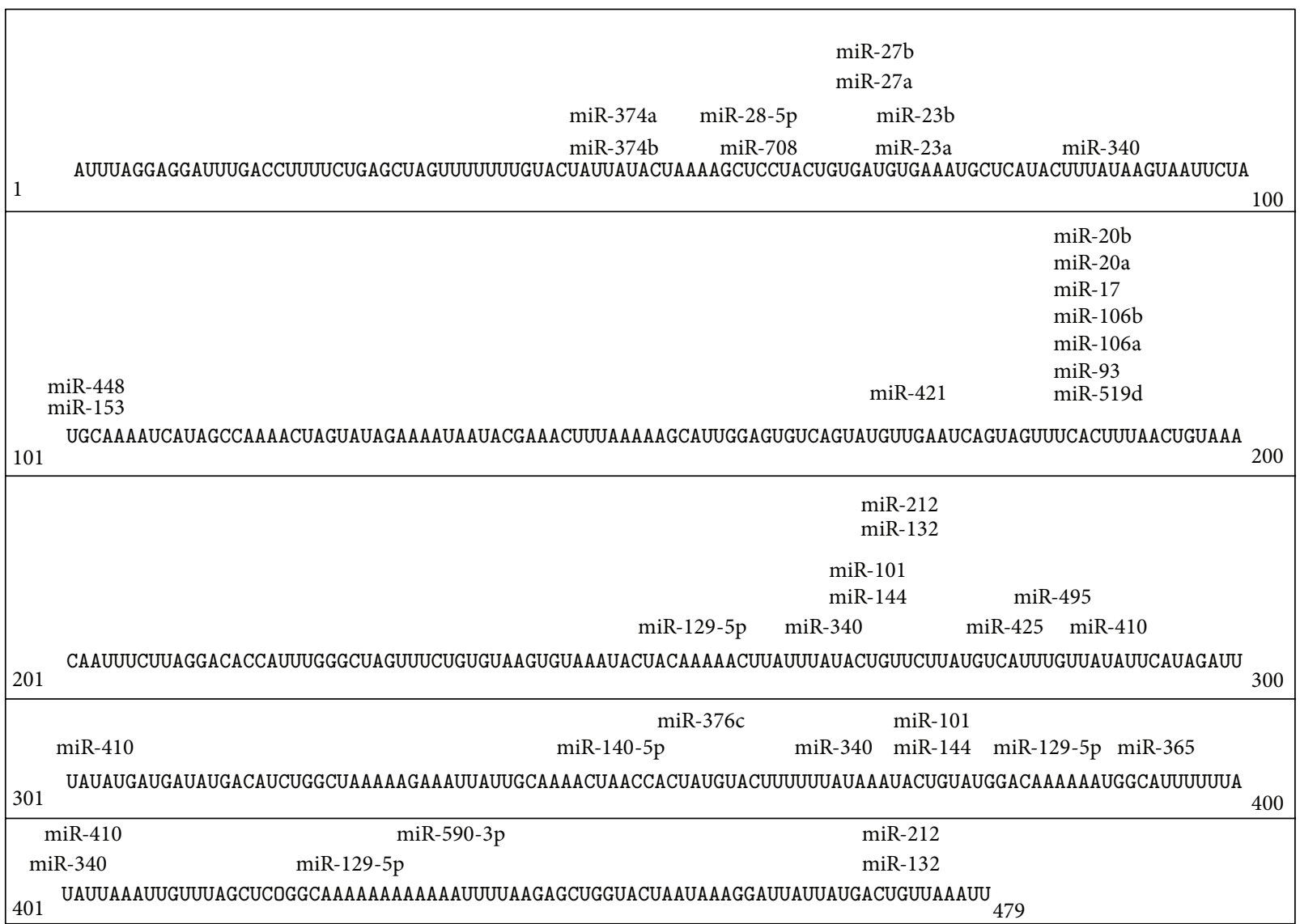

http://www.microrna.org/microrna/home.do

(a)

\begin{tabular}{|c|c|}
\hline $\begin{array}{l}\text { miR-129-5p } \\
{ }_{1} \text { GGCACUUUUGUUUCUUGGGCAAAAAUACAGUCCAAUGGGGAGUAUCAUUGUUUUUGUACAAAAACCGGGACUAAAAGAAAAGACAGCACUGCAAAUAACC }\end{array}$ & 100 \\
\hline $\begin{array}{c}\text { miR-200a } \\
\text { miR-141 } \\
101 \text { CAUCUUCCGGGAaGGGAGGCCAGGAUGCCUCAGUGUUAAAAUGACAUCUCAAAAGAAGUCCAAAGCGGGAAUCAUGUGCCCCUCAGCGGAGCCCCGGGAG }\end{array}$ & 200 \\
\hline 201 UGUCCAAGACAGCCUGGCUGGGAAAGGGGGUGUGGAAAGAGCAGGCUUCCAGGAGAGAGGCCCCCAAACCCUCUGGCCGGGUAAUAGGCCUGGGUCCCAC & 300 \\
\hline $\begin{array}{l}\text { UCACCCAUGCCGGCAGCUGUCACCAUGUGAUUUAUUCUUGGAUACCUGGGAGGGGGCCAAUGGGGGCCUCAGGGGGAGGCCCCCUCUGGAAAUGUGGUUC } \\
301\end{array}$ & 400 \\
\hline $\begin{array}{l}\text { miR-4 91-5p miR-421 miR-296-3p } \\
401 \text { CCAGGGAUGGGCCUGUACAUAGAAGCCACCGGAUGGCACUUCCCCACCGGAUGGACAGUUAUUUUGUUGAUAAGUAACCCUGUAAUUUCCAAGGAAAAU }\end{array}$ & 500 \\
\hline 501 AAAGAACAGACUAACUAGUGUCUUUCACCCUG 532 & \\
\hline
\end{tabular}

http://www.microrna.org/microrna/home.do

(b)

FiguRE 4: Predicted binding sites of conserved microRNAs of Nrf2 (a) and Keap1 (b) as identified by http://www.microrna.org/microrna/ home.do. 


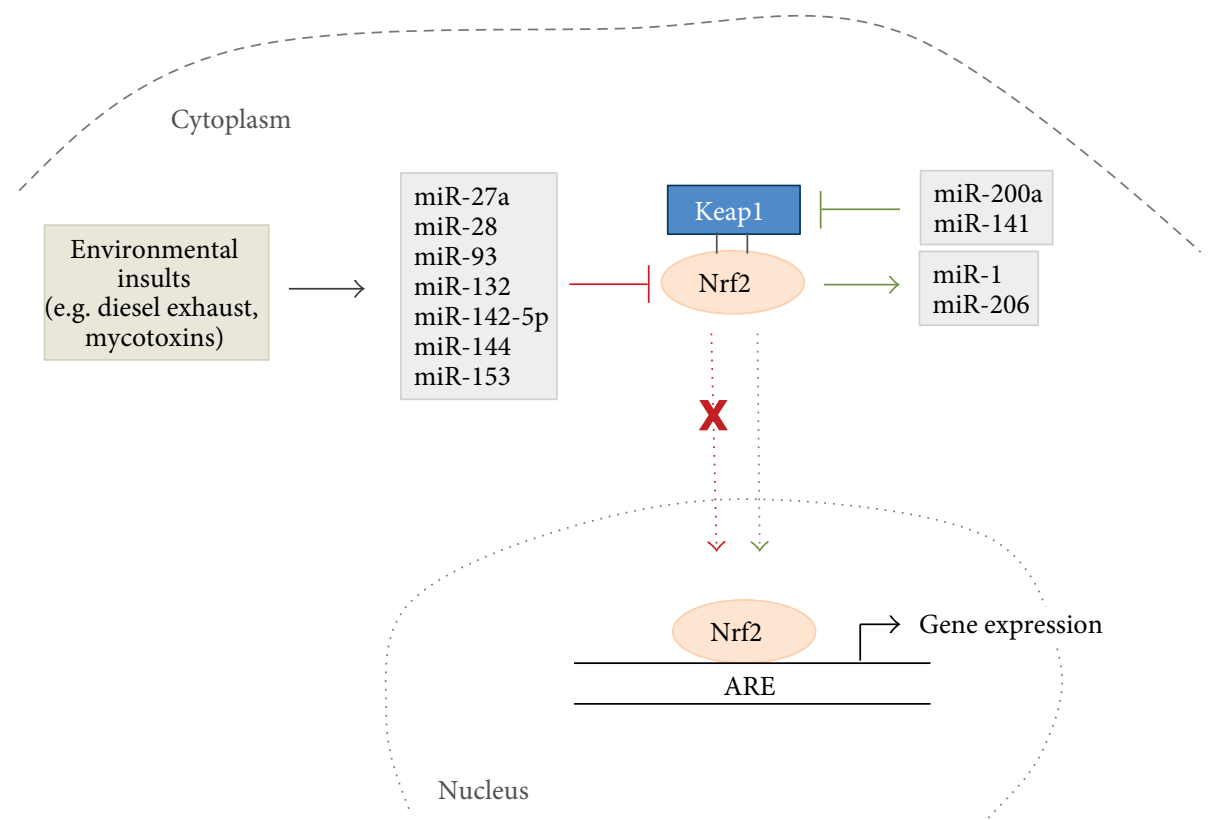

FIgURE 5: MicroRNAs being involved in the regulation of Nrf2 and Keap1.

the base pair complementarity between microRNA and target mRNA, to a decreased translation and mRNA degradation, respectively $[92,93]$. MicroRNAs are involved in a number of several cellular processes in the organism including development, cell-proliferation, differentiation, and apoptosis [91, $94,95]$. There are some data pointing to the notion that Brassica derived phytochemicals modulate miRNA expression suggesting that this is one mechanism of how these compounds may mediate health promoting activity. Slaby and coworkers [96] treated the colonic epithelial cell lines NCM460 and NCM356 with the isothiocyanates iberin and SFN which resulted in the regulation of three common microRNAs - miR-155, miR-23b, and miR-27b. Interestingly, it has been found that PEITC affects miR-141 in LnCaP cells, a microRNA which has been closely linked to the development of prostate cancer [97]. Also Basu and colleagues [98] observed microRNA-modulating effects according to isothiocyanate treatment of mice suffering from pancreatic intraepithelial neoplasia. The authors identified an inhibition of miR-221 and miR-375 following benzyl-ITC treatment changing hyperproliferative into hypoproliferative pancreatic cancer cells. Our own studies revealed an inhibitory effect of allyl-isothiocyanate (AITC) and SFN on the proinflammatory and oncogenic miR-155 in RAW264.7 murine macrophages [99]. In the lungs of mice exposed to environmental cigarette smoke microRNA expression has been altered which could be counteracted by PEITC treatment. However, some side effects of PEITC, including dysregulation of hepatic microRNAs, have been observed which should be investigated in more detail $[100,101]$. Furthermore, the brassica derived phytochemical I3C has been shown to reverse vinyl-carbamate induced de-regulation of microRNAs and the I3C dimer DIM increased miR-146a expression which in turn resulted in a decrease of cell invasion [102,
103]. To predict microRNA binding sites in the $3^{\prime} \mathrm{UTR}$ of different genes internet based prediction tools, including http://www.microrna.org/microrna/home.do, are available. According to http://www.microrna.org/microrna/home.do more than 40 conserved microRNAs may bind to Nrf2 (Figure 4(a)). However, only a small number of microRNAs, including miR-28, miR-93, miR-144, miR-153, miR-27a, miR132, and miR142-5p, have been confirmed experimentally to directly bind to the $3^{\prime} \mathrm{UTR}$ of Nrf2 and consequently downregulate gene expression [104-108]. Most of the microRNAs discussed in the literature to impact Nrf2 are affecting the expression of the transcription factor indirectly. Eades and coworkers [109] observed that miR-200a degrades Keap1 mRNA which in turn causes an increase of Nrf2 levels in breast cancer cells. A recent study conducted by Petrelli and colleagues [110] confirmed the effect of miR200a in preneoplastic lesions, where miR-200a also lowered Keap1 expression resulting in an Nrf2 increase. Also miR141 binds to Keap1 which results in increased Nrf2 levels [111]. http://www.microrna.org/microrna/home.do suggests five conserved microRNAs to bind to Keapl from which already two have been confirmed to effectively target the $3^{\prime}$ UTR of Keapl (Figure 4(b)).

The expression of Nrf2 regulating microRNAs is modulated by several environmental insults including diesel exhaust [112] and the mycotoxin ochratoxin A [108]. Interestingly, a study conducted by Singh and coworkers suggests that Nrf2 itself targets microRNAs. The authors observed an increase of miR-1 and miR-206 levels while Nrf2 is simultaneously upregulated [113]. Figure 5 gives an overview of how microRNAs are involved in Nrf2/Keap1 signaling. Table 1 lists confirmed microRNAs that target the promoter region of Nrf2 and Keap1. 


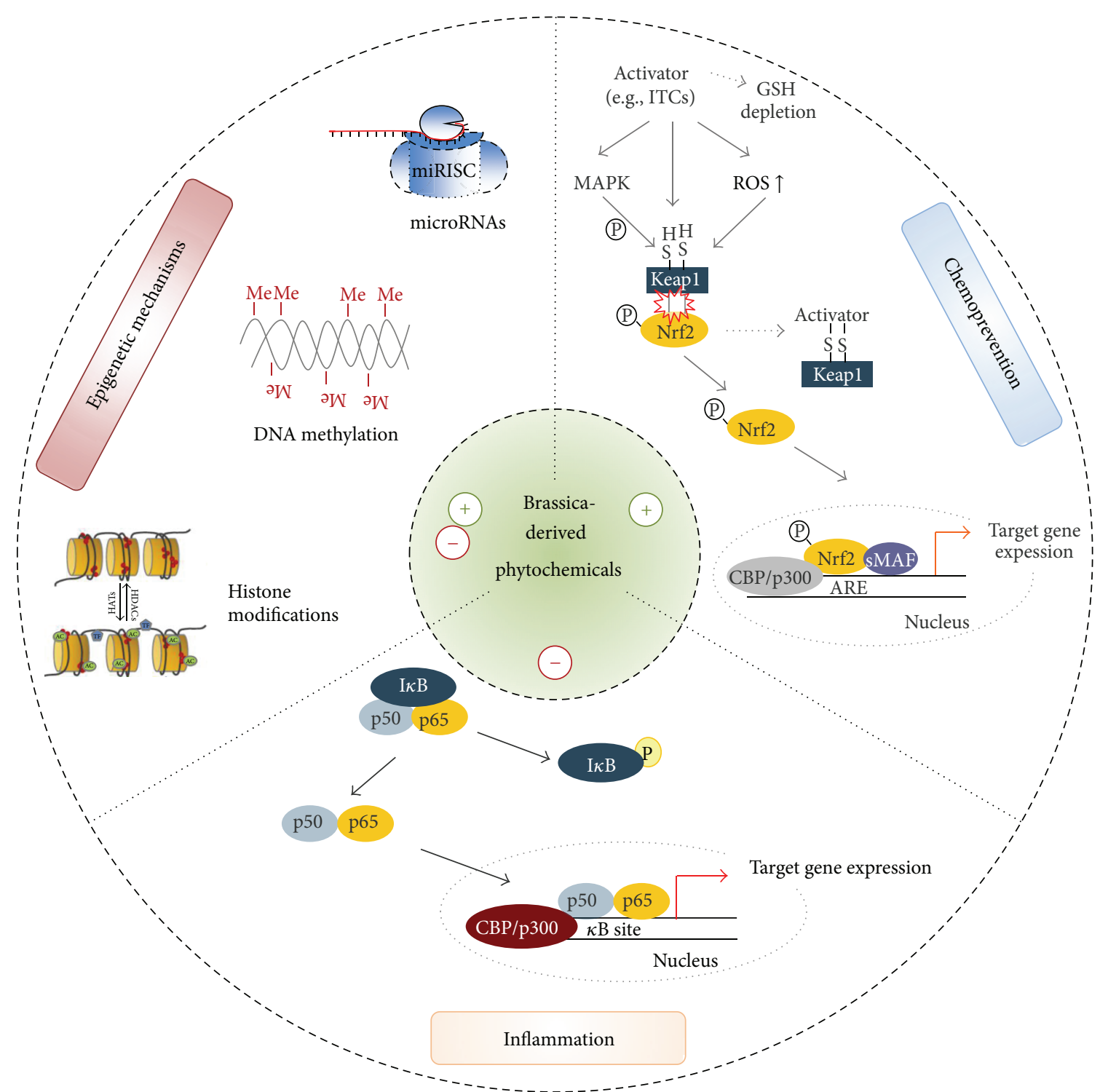

Figure 6: Potential chemopreventive, anti-inflammatory and epigenetic mechanisms by which brassica-derived phytochemicals may mediate health benefits (partly adapted from [11, 115-118]).

\section{Summary and Conclusion}

ITCs are one of the major degradation products of glucosinolates derived from brassica vegetables and are partly held to be responsible for the health promoting effects observed in populations with a high consumption of Brassicaceae. The health promoting effects of a diet rich in Brassica vegetables have been known for several decades and seem to be a promising starting point for, for example, the development of chemopreventive and anti-inflammatory functional foods, dietary supplements, and drugs. Figure 6 gives an overview of how brassica-derived phytochemicals may mediate their health-promoting activity. An increasing number of studies deal with ITC effects on the chemopreventive transcription factor Nrf2 and its corresponding target genes including antioxidant and phase 2 enzymes. In addition to studies in cultured cells beneficial effects of ITC have also been confirmed in vivo in laboratory rodents and humans. Also the anti-inflammatory effects of ITCs are well documented in both cell culture and in vivo studies. The applied concentrations of brassica derived phytochemicals range between 0.25 and $100 \mu \mathrm{mol} / \mathrm{L}$ in in vitro studies and up to $90 \mathrm{mg} / \mathrm{kg}$ BW in mouse studies. However, with regard to ITC effects on epigenetic mechanisms including histone modifications, DNA methylation, and microRNAs only a limited number of studies are currently available. In this context several studies have been performed in cultured cells and have revealed an increase in epigenetic targets connected with an inhibition of HDAC and DNMT as well as on microRNA expression. However, data concerning the modulation of epigenetic targets by ITCs especially in humans are, by and large, lacking even though epigenetic targets seem to play an 
TABLE 1: MicroRNAs inhibiting transcription factor Nrf2 and its inhibitor protein Keap1.

\begin{tabular}{llc}
\hline MicroRNA targeting Nrf2 & Research model & Reference \\
\hline miR-27a & SH-SY5Y cells & {$[105]$} \\
miR-28 & MCF-7 cells & {$[104]$} \\
\multirow{2}{*}{ miR-93 } & MCF-10A cells & \\
& T47D cells & {$[107]$} \\
miR-132 & ACI rats & \\
miR-142-5p & LLC-PK1 cells & {$[108]$} \\
miR-144 & SH-SY5Y cells & {$[105]$} \\
miR-153 & K562 cells & {$[106]$} \\
MicroRNA targeting Keap1 & Research model & Reference \\
\hline \multirow{3}{*}{ miR-141 } & A2780 cells & \\
& TOV112D cells & {$[111]$} \\
miR-200a & TPV21G cells & \\
& MDA-MB-231 cells & \\
\hline
\end{tabular}

essential role in the development of different kinds of cancer and may depict a promising target to prevent and/or treat chronic diseases.

\section{Acknowledgments}

Anika Eva Wagner is supported by a grant from the Deutsche Forschungsgemeinschaft (DFG; WA 3370/1-1) and the DFG cluster of excellence "Inflammation at Interfaces."

\section{References}

[1] D. T. H. Verhoeven, R. A. Goldbohm, G. Van Poppel, H. Verhagen, and P. A. Van Den Brandt, "Epidemiological studies on Brassica vegetables and cancer risk," Cancer Epidemiology Biomarkers and Prevention, vol. 5, no. 9, pp. 733-748, 1996.

[2] D. T. H. Verhoeven, H. Verhagen, R. A. Goldbohm, P. A. Van Den Brandt, and G. Van Poppel, "A review of mechanisms underlying anticarcinogenicity by brassica vegetables," Chemico-Biological Interactions, vol. 103, no. 2, pp. 79-129, 1997.

[3] L. E. Voorrips, R. A. Goldbohm, G. Van Poppel, F. Sturmans, R. J. J. Hermus, and P. A. Van Den Brandt, "Vegetable and fruit consumption and risks of colon and rectal cancer in a prospective cohort study: the Netherlands Cohort Study on Diet and Cancer," American Journal of Epidemiology, vol. 152, no. 11, pp. 1081-1092, 2000.

[4] A. T. Dinkova-Kostova and R. V. Kostov, "Glucosinolates and isothiocyanates in health and disease," Trends in Molecular Medicine, vol. 18, pp. 337-347, 2012.

[5] A. Melchini, C. Costa, M. Traka et al., "Erucin, a new promising cancer chemopreventive agent from rocket salads, shows antiproliferative activity on human lung carcinoma A549 cells," Food and Chemical Toxicology, vol. 47, no. 7, pp. 1430-1436, 2009.

[6] C. Bonnesen, I. M. Eggleston, and J. D. Hayes, "Dietary indoles and isothiocyanates that are generated from cruciferous vegetables can both stimulate apoptosis and confer protection against
DNA damage in human colon cell lines," Cancer Research, vol. 61, no. 16, pp. 6120-6130, 2001.

[7] R. Munday and C. M. Munday, "Induction of phase II detoxification enzymes in rats by plant-derived isothiocyanates: comparison of allyl isothiocyanate with sulforaphane and related compounds," Journal of Agricultural and Food Chemistry, vol. 52, no. 7, pp. 1867-1871, 2004.

[8] A. F. A. Razis, M. Bagatta, G. R. De Nicola, R. Iori, and C. Ioannides, "Intact glucosinolates modulate hepatic cytochrome P450 and phase II conjugation activities and may contribute directly to the chemopreventive activity of cruciferous vegetables," Toxicology, vol. 277, no. 1-3, pp. 74-85, 2010.

[9] S. L. Navarro, F. Li, and J. W. Lampe, "Mechanisms of action of isothiocyanates in cancer chemoprevention: an update," Food and Function, vol. 2, no. 10, pp. 579-587, 2011.

[10] R. Verkerk, M. Schreiner, A. Krumbein et al., "Glucosinolates in Brassica vegetables: the influence of the food supply chain on intake, bioavailability and human health," Molecular Nutrition and Food Research, vol. 53, no. 2, pp. 219-265, 2009.

[11] J. D. Hayes, M. O. Kelleher, and I. M. Eggleston, “The cancer chemopreventive actions of phytochemicals derived from glucosinolates," European Journal of Nutrition, vol. 47, no. 2, pp. 73$88,2008$.

[12] N. Juge, R. F. Mithen, and M. Traka, "Molecular basis for chemoprevention by sulforaphane: a comprehensive review," Cellular and Molecular Life Sciences, vol. 64, no. 9, pp. 1105-1127, 2007.

[13] L. G. Wang, A. Beklemisheva, X. M. Liu, A. C. Ferrari, J. Feng, and J. W. Chiao, "Dual action on promoter demethylation and chromatin by an isothiocyanate restored GSTP1 silenced in prostate cancer," Molecular Carcinogenesis, vol. 46, no. 1, pp. 2431, 2007.

[14] A. Gong, M. He, D. K. Vanaja, P. Yin, R. Jeffrey Karnes, and C. Y. F. Young, "Phenethyl isothiocyanate inhibits STAT3 activation in prostate cancer cells," Molecular Nutrition and Food Research, vol. 53, no. 7, pp. 878-886, 2009.

[15] X.-H. Wang, B. E. Cavell, S. S. S. Alwi, and G. Packham, "Inhibition of hypoxia inducible factor by phenethyl isothiocyanate," Biochemical Pharmacology, vol. 78, no. 3, pp. 261-272, 2009.

[16] J.-K. Moon, J.-R. Kim, Y.-J. Ahn, and T. Shibamoto, "Analysis and anti- helicobacter activity of sulforaphane and related compounds present in Broccoli (Brassica oleracea L.) sprouts," Journal of Agricultural and Food Chemistry, vol. 58, no. 11, pp. 6672-6677, 2010.

[17] J. J. Michnovicz and H. L. Bradlow, "Altered estrogen metabolism and excretion in humans following consumption of indole-3-carbinol," Nutrition and Cancer, vol. 16, no. 1, pp. 59-66, 1991.

[18] A. Yanaka, J. W. Fahey, A. Fukumoto et al., "Dietary sulforaphane-rich broccoli sprouts reduce colonization and attenuate gastritis in Helicobacter pylori-infected mice and humans," Cancer Prevention Research, vol. 2, no. 4, pp. 353-360, 2009.

[19] S. C. Gupta, J. H. Kim, S. Prasad, and B. B. Aggarwal, "Regulation of survival, proliferation, invasion, angiogenesis, and metastasis of tumor cells through modulation of inflammatory pathways by nutraceuticals," Cancer and Metastasis Reviews, vol. 29 , no. 3, pp. 405-434, 2010.

[20] Y.-J. Surh and H.-K. Na, "NF- $\kappa$ B and Nrf2 as prime molecular targets for chemoprevention and cytoprotection with antiinflammatory and antioxidant phytochemicals," Genes and Nutrition, vol. 2, no. 4, pp. 313-317, 2008. 
[21] S. C. Gupta, C. Sundaram, S. Reuter, and B. B. Aggarwal, "Inhibiting NF- $\kappa$ B activation by small molecules as a therapeutic strategy," Biochimica et Biophysica Acta, vol. 1799, no. 10-12, pp. 775-787, 2010.

[22] L. F. Chen and W. C. Greene, "Shaping the nuclear action of NF«B," Nature Reviews Molecular Cell Biology, vol. 5, pp. 392-401, 2004.

[23] F. Chen, V. Castranova, and X. Shi, "New insights into the role of nuclear factor- $\kappa \mathrm{B}$ in cell growth regulation," American Journal of Pathology, vol. 159, no. 2, pp. 387-397, 2001.

[24] E. Shaulian and M. Karin, "AP-1 in cell proliferation and survival," Oncogene, vol. 20, no. 19, pp. 2390-2400, 2001.

[25] E. Shaulian and M. Karin, "AP-1 as a regulator of cell life and death," Nature Cell Biology, vol. 4, no. 5, pp. E131-E136, 2002.

[26] E. Heiss, C. Herhaus, K. Klimo, H. Bartsch, and C. Gerhäuser, "Nuclear factor $\kappa \mathrm{B}$ is a molecular target for sulforaphanemediated anti-inflammatory mechanisms," The Journal of Biological Chemistry, vol. 276, no. 34, pp. 32008-32015, 2001.

[27] W.-S. Jeong, I.-W. Kim, R. Hu, and A.-N. T. Kong, "Modulatory properties of various natural chemopreventive agents on the activation of NF- $\kappa \mathrm{B}$ signaling pathway," Pharmaceutical Research, vol. 21, no. 4, pp. 661-670, 2004.

[28] K. J. Woo and T. K. Kwon, "Sulforaphane suppresses lipopolysaccharide-induced cyclooxygenase-2 (COX-2) expression through the modulation of multiple targets in COX-2 gene promoter," International Immunopharmacology, vol. 7, no. 13, pp. 1776-1783, 2007.

[29] Y.-H. Chen, H.-J. Dai, and H.-P. Chang, "Suppression of inducible nitric oxide production by indole and isothiocyanate derivatives from Brassica plants in stimulated macrophages," Planta Medica, vol. 69, no. 8, pp. 696-700, 2003.

[30] A. Prawan, C. L. L. Saw, T. O. Khor et al., "Anti-NF- $\kappa$ B and antiinflammatory activities of synthetic isothiocyanates: effect of chemical structures and cellular signaling," Chemico-Biological Interactions, vol. 179, no. 2-3, pp. 202-211, 2009.

[31] P. Rose, K. W. Yen, N. O. Choon, and M. Whiteman, “ $\beta$ Phenylethyl and 8-methylsulphinyloctyl isothiocyanates, constituents of watercress, suppress LPS induced production of nitric oxide and prostaglandin E2 in RAW 264.7 macrophages," Nitric Oxide, vol. 12, no. 4, pp. 237-243, 2005.

[32] Y. H. Kim, H.-S. Kwon, D. H. Kim et al., "3,3/-diindolylmethane attenuates colonic inflammation and tumorigenesis in mice," Inflammatory Bowel Diseases, vol. 15, no. 8, pp. 1164-1173, 2009.

[33] A. E. Wagner, O. Will, C. Sturm, S. Lipinski et al., "DSS-induced acute colitis in C57BL/6 mice is mitigated by sulforaphane pretreatment," The Journal of Nutritional Biochemistry, vol. 25, pp. 2085-2091, 2013.

[34] Y.-S. Keum, W.-S. Jeong, and A. N. Tony Kong, "Chemoprevention by isothiocyanates and their underlying molecular signaling mechanisms," Mutation Research, vol. 555, no. 1-2, pp. 191-202, 2004.

[35] Y. Shan, R. Zhao, W. Geng et al., "Protective effect of sulforaphane on human vascular endothelial cells against lipopolysaccharide-induced inflammatory damage," Cardiovascular Toxicology, vol. 10, no. 2, pp. 139-145, 2010.

[36] C. Xu, G. Shen, C. Chen, C. Gélinas, and A.-N. T. Kong, "Suppression of NF- $\kappa \mathrm{B}$ and NF- $\kappa \mathrm{B}$-regulated gene expression by sulforaphane and PEITC through $\mathrm{I} \kappa \mathrm{B} \alpha$, IKK pathway in human prostate cancer PC-3 cells," Oncogene, vol. 24, no. 28, pp. 44864495, 2005.
[37] M.-D. Yang, K.-C. Lai, T.-Y. Lai et al., "Phenethyl isothiocyanate inhibits migration and invasion of human gastric cancer AGS cells through suppressing MAPK and NF- $\kappa$ B signal pathways," Anticancer Research, vol. 30, no. 6, pp. 2135-2143, 2010.

[38] P. Anand, A. B. Kunnumakkara, K. B. Harikumar, S. A. Kwang, V. Badmaev, and B. B. Aggarwal, "Modification of cysteine residue in $\mathrm{p} 65$ subunit of nuclear factor $-\kappa \mathrm{B}(\mathrm{NF}-\kappa \mathrm{B})$ by picroliv suppresses NF- $\kappa \mathrm{B}$-regulated gene products and potentiates apoptosis," Cancer Research, vol. 68, no. 21, pp. 8861-8870, 2008.

[39] E. Heiss and C. Gerhäuser, "Time-dependent modulation of thioredoxin reductase activity might contribute to sulforaphane-mediated inhibition of NF- $\kappa \mathrm{B}$ binding to DNA," Antioxidants and Redox Signaling, vol. 7, no. 11-12, pp. 1601-1611, 2005.

[40] Y.-J. Surh, "Cancer chemoprevention with dietary phytochemicals," Nature Reviews Cancer, vol. 3, no. 10, pp. 768-780, 2003.

[41] Y.-J. Surh, J. K. Kundu, H.-K. Na, and J.-S. Lee, "Redox-sensitive transcription factors as prime targets for chemoprevention with anti-inflammatory and antioxidative phytochemicals," Journal of Nutrition, vol. 135, no. 12, pp. 2993S-3001S, 2005.

[42] T. O. Khor, M.-T. Huang, K. H. Kwon, J. Y. Chan, B. S. Reddy, and A.-N. Kong, "Nrf2-deficient mice have an increased susceptibility to dextran sulfate sodium-induced colitis," Cancer Research, vol. 66, no. 24, pp. 11580-11584, 2006.

[43] E. Balogun, M. Hoque, P. Gong et al., "Curcumin activates the haem oxygenase-1 gene via regulation of $\mathrm{Nrf2}$ and the antioxidant-responsive element," Biochemical Journal, vol. 371, no. 3, pp. 887-895, 2003.

[44] R. K. Thimmulappa, H. Lee, T. Rangasamy et al., "Nrf2 is a critical regulator of the innate immune response and survival during experimental sepsis," The Journal of Clinical Investigation, vol. 116, no. 4, pp. 984-995, 2006.

[45] A. E. Wagner, I. Ernst, R. Iori, C. Desel, and G. Rimbach, "Sulforaphane but not ascorbigen, indole-3-carbinole and ascorbic acid activates the transcription factor Nrf2 and induces phase2 and antioxidant enzymes in human keratinocytes in culture," Experimental Dermatology, vol. 19, no. 2, pp. 137-144, 2010.

[46] C. Xu, M.-T. Huang, G. Shen et al., "Inhibition of 7,12dimethylbenz(a)anthracene-induced skin tumorigenesis in C57BL/6 mice by sulforaphane is mediated by nuclear factor E2-related factor 2," Cancer Research, vol. 66, no. 16, pp. 8293-8296, 2006.

[47] Y.-S. Keum, "Regulation of the Keap1/Nrf2 system by chemopreventive sulforaphane: implications of posttranslational modifications," Annals of the New York Academy of Sciences, vol. 1229, no. 1, pp. 184-189, 2011.

[48] C. L. Saw, M.-T. Huang, Y. Liu, T. O. Khor, A. H. Conney, and A.-N. Kong, "Impact of Nrf2 on UVB-induced skin inflammation/photoprotection and photoprotective effect of sulforaphane," Molecular Carcinogenesis, vol. 50, no. 6, pp. 479486, 2011.

[49] I. M. A. Ernst, A. E. Wagner, C. Schuemann et al., "Allyl-, butyl- and phenylethyl-isothiocyanate activate Nrf2 in cultured fibroblasts," Pharmacological Research, vol. 63, no. 3, pp. 233240, 2011.

[50] C. L.-L. Saw, M. Cintrón, T.-Y. Wu et al., "Pharmacodynamics of dietary phytochemical indoles I3C and DIM: induction of Nrf2mediated phase II drug metabolizing and antioxidant genes and synergism with isothiocyanates," Biopharmaceutics and Drug Disposition, vol. 32, no. 5, pp. 289-300, 2011.

[51] G.-H. Liu, J. Qu, and X. Shen, "NF- $\kappa$ B/p65 antagonizes Nrf2ARE pathway by depriving CBP from Nrf2 and facilitating 
recruitment of HDAC3 to MafK," Biochimica et Biophysica Acta, vol. 1783, no. 5, pp. 713-727, 2008.

[52] H. Yang, N. Magilnick, X. Ou, and S. C. Lu, "Tumour necrosis factor $\alpha$ induces co-ordinated activation of rat GSH synthetic enzymes via nuclear factor $\kappa \mathrm{B}$ and activator protein-1," Biochemical Journal, vol. 391, no. 2, pp. 399-408, 2005.

[53] G. Egger, G. Liang, A. Aparicio, and P. A. Jones, "Epigenetics in human disease and prospects for epigenetic therapy," Nature, vol. 429, no. 6990, pp. 457-463, 2004.

[54] J. Winter, S. Jung, S. Keller, R. I. Gregory, and S. Diederichs, "Many roads to maturity: microRNA biogenesis pathways and their regulation," Nature Cell Biology, vol. 11, no. 3, pp. 228-234, 2009.

[55] C. B. Yoo and P. A. Jones, "Epigenetic therapy of cancer: past, present and future," Nature Reviews Drug Discovery, vol. 5, no. 1, pp. 37-50, 2006.

[56] C. Gerhauser, "Cancer chemoprevention and nutriepigenetics: state of the art and future challenges," Topics in Current Chemistry, vol. 329, pp. 73-132, 2013.

[57] T. Esatbeyoglu, P. Huebbe, I. M. Ernst, D. Chin et al., "Curcumin-from molecule to biological function," Angewandte Chemie International Edition, vol. 51, no. 22, pp. 5308-5332, 2012.

[58] R. Kanwal and S. Gupta, "Epigenetics and cancer," Journal of Applied Physiology, vol. 109, no. 2, pp. 598-605, 2010.

[59] S. Reuter, S. C. Gupta, B. Park, A. Goel, and B. B. Aggarwal, "Epigenetic changes induced by curcumin and other natural compounds," Genes and Nutrition, vol. 6, no. 2, pp. 93-108, 2011.

[60] Y. Li, Y. I. Hassan, H. Moriyama, and J. Zempleni, "Holocarboxylase synthetase interacts physically with euchromatic histone-lysine $N$, linking histone biotinylation with methylation events," The Journal of Nutritional Biochemistry, vol. 24, no. 8, pp. 1446-1452, 2013.

[61] J. Xue, S. S. Wijeratne, and J. Zempleni, "Holocarboxylase synthetase synergizes with methyl CpG binding protein 2 and DNA methyltransferase 1 in the transcriptional repression of long-terminal repeats," Epigenetics, vol. 8, pp. 504-511, 2013.

[62] K. Zhang and S. Y. R. Dent, "Histone modifying enzymes and cancer: going beyond histones," Journal of Cellular Biochemistry, vol. 96, no. 6, pp. 1137-1148, 2005.

[63] S. Saini, S. Arora, S. Majid et al., "Curcumin modulates microRNA-203-mediated regulation of the Src-Akt axis in bladder cancer," Cancer Prevention Research, vol. 4, no. 10, pp. 1698-1709, 2011.

[64] S. Spiegel, S. Milstien, and S. Grant, "Endogenous modulators and pharmacological inhibitors of histone deacetylases in cancer therapy," Oncogene, vol. 31, no. 5, pp. 537-551, 2012.

[65] W. S. Xu, R. B. Parmigiani, and P. A. Marks, "Histone deacetylase inhibitors: molecular mechanisms of action," Oncogene, vol. 26, no. 37, pp. 5541-5552, 2007.

[66] P. Rajendran, D. E. Williams, E. Ho, and R. H. Dashwood, "Metabolism as a key to histone deacetylase inhibition," Critical Reviews in Biochemistry and Molecular Biology, vol. 46, no. 3, pp. 181-199, 2011.

[67] P. Rajendran, A. I. Kidane, T. W. Yu, W. M. Dashwood et al., "HDAC turnover, CtIP acetylation and dysregulated DNA damage signaling in colon cancer cells treated with sulforaphane and related dietary isothiocyanates," Epigenetics, vol. 8, no. 6, pp. 612-623, 2013.

[68] P. Rajendran, B. Delage, W. M. Dashwood et al., "Histone deacetylase turnover and recovery in sulforaphane-treated colon cancer cells: competing actions of 14-3-3 and Pin1 in
HDAC3/SMRT corepressor complex dissociation/reassembly," Molecular Cancer, vol. 10, article 68, 2011.

[69] J. D. Clarke, A. Hsu, Z. Yu, R. H. Dashwood, and E. Ho, "Differential effects of sulforaphane on histone deacetylases, cell cycle arrest and apoptosis in normal prostate cells versus hyperplastic and cancerous prostate cells," Molecular Nutrition and Food Research, vol. 55, no. 7, pp. 999-1009, 2011.

[70] M. C. Myzak, K. Hardin, R. Wang, R. H. Dashwood, and E. Ho, "Sulforaphane inhibits histone deacetylase activity in BPH1, LnCaP and PC-3 prostate epithelial cells," Carcinogenesis, vol. 27, no. 4, pp. 811-819, 2006.

[71] A. Pledgie-Tracy, M. D. Sobolewski, and N. E. Davidson, "Sulforaphane induces cell type-specific apoptosis in human breast cancer cell lines," Molecular Cancer Therapeutics, vol. 6, no. 3, pp. 1013-1021, 2007.

[72] M. C. Myzak, W. M. Dashwood, G. A. Orner, E. Ho, and R. H. Dashwood, "Sulforaphane inhibits histone deacetylase in vivo and suppresses tumorigenesis in Apcmin mice," FASEB Journal, vol. 20, no. 3, pp. 506-508, 2006.

[73] M. C. Myzak, P. Tong, W.-M. Dashwood, R. H. Dashwood, and E. Ho, "Sulforaphane retards the growth of human PC3 xenografts and inhibits HDAC activity in human subjects," Experimental Biology and Medicine, vol. 232, no. 2, pp. 227-234, 2007.

[74] L. G. Wang, X. M. Liu, Y. Fang et al., "De-repression of the p21 promoter in prostate cancer cells by an isothiocyanate via inhibition of HDACs and c-Myc," International Journal of Oncology, vol. 33, no. 2, pp. 375-380, 2008.

[75] A. A. Beklemisheva, Y. Fang, J. Feng, X. Ma, W. Dai, and J. W. Chiao, "Epigenetic mechanism of growth inhibition induced by phenylhexyl isothiocyanate in prostate cancer cells," Anticancer Research, vol. 26, no. 2 A, pp. 1225-1230, 2006.

[76] Q. Lu, X. Lin, J. Feng et al., "Phenylhexyl isothiocyanate has dual function as histone deacetylase inhibitor and hypomethylating agent and can inhibit myeloma cell growth by targeting critical pathways," Journal of hematology \& oncology, vol. 1, p. 6, 2008.

[77] X. Ma, Y. Fang, A. Beklemisheva et al., "Phenylhexyl isothiocyanate inhibits histone deacetylases and remodels chromatins to induce growth arrest in human leukemia cells," International Journal of Oncology, vol. 28, no. 5, pp. 1287-1293, 2006.

[78] S. Batra, R. P. Sahu, P. K. Kandala, and S. K. Srivastava, "Benzyl isothiocyanate-mediated inhibition of histone deacetylase leads to NF- $\kappa \mathrm{B}$ turnoff in human pancreatic carcinoma cells," Molecular Cancer Therapeutics, vol. 9, no. 6, pp. 1596-1608, 2010.

[79] L. M. Beaver, T. W. Yu, E. I. Sokolowski, D. E. Williams et al., "3, 3'-Diindolylmethane, but not indole-3-carbinol, inhibits histone deacetylase activity in prostate cancer cells," Toxicol Appl Pharmacol, vol. 263, no. 3, pp. 345-351, 2012.

[80] R. H. Dashwood and E. Ho, "Dietary histone deacetylase inhibitors: from cells to mice to man," Seminars in Cancer Biology, vol. 17, no. 5, pp. 363-369, 2007.

[81] M. Esteller, "Cancer epigenomics: DNA methylomes and histone-modification maps," Nature Reviews Genetics, vol. 8, no. 4, pp. 286-298, 2007.

[82] A. Hermann, H. Gowher, and A. Jeltsch, "Biochemistry and biology of mammalian DNA methyltransferases," Cellular and Molecular Life Sciences, vol. 61, no. 19-20, pp. 2571-2587, 2004.

[83] G. H. Kang, H. J. Lee, K. S. Hwang, S. Lee, J.-H. Kim, and J.-S. Kim, "Aberrant CpG island hypermethylation of chronic gastritis, in relation to aging, gender, intestinal metaplasia, and chronic inflammation," American Journal of Pathology, vol. 163, no. 4, pp. 1551-1556, 2003. 
[84] S. M. Meeran, S. N. Patel, and T. O. Tollefsbol, "Sulforaphane causes epigenetic repression of hTERT expression in human breast cancer cell lines," PLOS ONE, vol. 5, no. 7, Article ID e11457, 2010.

[85] L. N. Barrera, I. T. Johnson, Y. Bao, A. Cassidy et al., "Colorectal cancer cells Caco-2 and HCT116 resist epigenetic effects of isothiocyanates and selenium in vitro," European Journal of Nutrition, vol. 52, no. 4, pp. 1327-1341, 2013.

[86] A. Hsu, C. P. Wong, Z. Yu, D. E. Williams et al., "Promoter de-methylation of cyclin D2 by sulforaphane in prostate cancer cells," Clin Epigenetics, vol. 3, no. 1, 2011.

[87] H. Fan, R. Zhang, D. Tesfaye, E. Tholen et al., "Sulforaphane causes a major epigenetic repression of myostatin in porcine satellite cells," Epigenetics, vol. 7, pp. 1379-1390, 2012.

[88] S. Jiang, X. Ma, Y. Huang, Y. Xu, R. Zheng, and J.-W. Chiao, "Reactivating aberrantly hypermethylated p15 gene in leukemic $T$ cells by a phenylhexyl isothiocyanate mediated inter-active mechanism on DNA and chromatin," Journal of Hematology and Oncology, vol. 3, article 48, 2010.

[89] R. M. O’Connell, K. D. Taganov, M. P. Boldin, G. Cheng, and D. Baltimore, "MicroRNA-155 is induced during the macrophage inflammatory response," Proceedings of the National Academy of Sciences of the United States of America, vol. 104, no. 5, pp. 16041609, 2007.

[90] K. D. Taganov, M. P. Boldin, K.-J. Chang, and D. Baltimore, "NF$\kappa \mathrm{B}$-dependent induction of microRNA miR-146, an inhibitor targeted to signaling proteins of innate immune responses," Proceedings of the National Academy of Sciences of the United States of America, vol. 103, no. 33, pp. 12481-12486, 2006.

[91] M. A. Valencia-Sanchez, J. Liu, G. J. Hannon, and R. Parker, "Control of translation and mRNA degradation by miRNAs and siRNAs," Genes and Development, vol. 20, no. 5, pp. 515-524, 2006.

[92] D. P. Bartel, "MicroRNAs: genomics, biogenesis, mechanism, and function," Cell, vol. 116, no. 2, pp. 281-297, 2004.

[93] L. He and G. J. Hannon, "MicroRNAs: small RNAs with a big role in gene regulation," Nature Reviews Genetics, vol. 5, no. 7, pp. 522-531, 2004.

[94] C. Boesch-Saadatmandi, A. Loboda, A. E. Wagner et al., "Effect of quercetin and its metabolites isorhamnetin and quercetin-3glucuronide on inflammatory gene expression: role of miR-155," Journal of Nutritional Biochemistry, vol. 22, no. 3, pp. 293-299, 2011.

[95] B. C. Bernardo, F. J. Charchar, R. C. Y. Lin, and J. R. McMullen, "A MicroRNA guide for clinicians and basic scientists: background and experimental techniques," Heart Lung and Circulation, vol. 21, no. 3, pp. 131-142, 2012.

[96] O. Slaby, M. Sachlova, V. Brezkova, R. Hezova et al., "Identification of microRNAs regulated by isothiocyanates and association of polymorphisms inside their target sites with risk of sporadic colorectal cancer," Nutrition and Cancer, vol. 65, no. 2, pp. 247254, 2013.

[97] J. Xiao, A.-Y. Gong, A. N. Eischeid et al., "miR-141 modulates androgen receptor transcriptional activity in human prostate cancer cells through targeting the small heterodimer partner protein," Prostate, vol. 72, pp. 1514-1522, 2012.

[98] A. Basu, H. Alder, A. Khiyami, P. Leahy, C. M. Croce, and S. Haldar, "MicroRNA-375 and microRNA-221: potential noncoding RNAs associated with antiproliferative activity of Benzyl isothiocyanate in pancreatic cancer," Genes and Cancer, vol. 2, no. 2, pp. 108-119, 2011.
[99] A. E. Wagner, C. Boesch-Saadatmandi, J. Dose, G. Schultheiss et al., "Anti-inflammatory potential of allyl-isothiocyanate-role of Nrf2, NF- $\kappa$ B and microRNA-155," J Cell Mol Med, vol. 16, pp. 836-843, 2012.

[100] A. Izzotti, P. Larghero, C. Cartiglia et al., "Modulation of microRNA expression by budesonide, phenethyl isothiocyanate and cigarette smoke in mouse liver and lung," Carcinogenesis, vol. 31, no. 5, pp. 894-901, 2010.

[101] A. Izzotti, G. A. Calin, V. E. Steele et al., "Chemoprevention of cigarette smoke-induced alterations of microRNA expression in rat lungs," Cancer Prevention Research, vol. 3, no. 1, pp. 62-72, 2010.

[102] Y. Li, D. Kong, Z. Wang, and F. H. Sarkar, "Regulation of microRNAs by natural agents: an emerging field in chemoprevention and chemotherapy research," Pharmaceutical Research, vol. 27, no. 6, pp. 1027-1041, 2010.

[103] Y. Li, T. G. VandenBoom II, Z. Wang et al., "miR-146a suppresses invasion of pancreatic cancer cells," Cancer Research, vol. 70, no. 4, pp. 1486-1495, 2010.

[104] M. Yang, Y. Yao, G. Eades, Y. Zhang, and Q. Zhou, "MiR28 regulates Nrf2 expression through a Keapl-independent mechanism," Breast Cancer Research and Treatment, vol. 129, no. 3, pp. 983-991, 2011.

[105] M. Narasimhan, D. Patel, D. Vedpathak, M. Rathinam et al., "Identification of novel microRNAs in post-transcriptional control of Nrf2 expression and redox homeostasis in neuronal, SH-SY5Y cells," PLoS ONE, vol. 7, 2012.

[106] C. Sangokoya, M. J. Telen, and J.-T. Chi, "microRNA miR-144 modulates oxidative stress tolerance and associates with anemia severity in sickle cell disease," Blood, vol. 116, no. 20, pp. 43384348, 2010.

[107] B. Singh, A. M. Ronghe, A. Chatterjee, N. K. Bhat et al., "MicroRNA-93 regulates NRF2 expression and is associated with breast carcinogenesis," Carcinogenesis, vol. 34, pp. 11651172, 2013.

[108] A. Stachurska, M. Ciesla, M. Kozakowska, S. Wolffram et al., "Cross-talk between microRNAs, nuclear factor E2-related factor 2, and heme oxygenase-1 in ochratoxin A-induced toxic effects in renal proximal tubular epithelial cells," Molecular Nutrition \& Food Research, vol. 57, no. 3, pp. 504-515, 2013.

[109] G. Eades, M. Yang, Y. Yao, Y. Zhang, and Q. Zhou, "miR-200a regulates Nrf2 activation by targeting Keap1 mRNA in breast cancer cells," The Journal of Biological Chemistry, vol. 286, no. 47, pp. 40725-40733, 2011.

[110] A. Petrelli, A. Perra, D. Cora, P. Sulas et al., "MiRNA/gene profiling unveils early molecular changes and NRF2 activation in a rat model recapitulating human HCC," Hepatology, vol. 2013, 2013.

[111] M. T. van Jaarsveld, J. Helleman, A. W. Boersma, P. F. van Kuijk et al., "miR-141 regulates KEAP1 and modulates cisplatin sensitivity in ovarian cancer cells," Oncogene, vol. 32, pp. 42844293, 2013.

[112] M. Yamamoto, A. Singh, F. Sava, M. Pui et al., "MicroRNA expression in response to controlled exposure to diesel exhaust: attenuation by the antioxidant $N$ in a randomized crossover study," Environ Health Perspect, vol. 121, pp. 670-675, 2013.

[113] A. Singh, C. Happel, S. K. Manna, G. Acquaah-Mensah et al., "Transcription factor NRF2 regulates miR-1 and miR-206 to drive tumorigenesis," The Journal of Clinical Investigation, vol. 123, pp. 2921-2934, 2013. 
[114] J. W. Fahey, A. T. Zalcmann, and P. Talalay, "The chemical diversity and distribution of glucosinolates and isothiocyanates among plants," Phytochemistry, vol. 56, no. 1, pp. 5-51, 2001.

[115] W.-S. Jeong, M. Jun, and A.-N. T. Kong, "Nrf2: a potential molecular target for cancer chemoprevention by natural compounds," Antioxidants and Redox Signaling, vol. 8, no. 1-2, pp. 99-106, 2006.

[116] T. Kouzarides, "Chromatin modifications and their function," Cell, vol. 128, no. 4, pp. 693-705, 2007.

[117] I. Rahman, J. Marwick, and P. Kirkham, "Redox modulation of chromatin remodeling: impact on histone acetylation and deacetylation, NF- $\kappa \mathrm{B}$ and pro-inflammatory gene expression," Biochemical Pharmacology, vol. 68, no. 6, pp. 1255-1267, 2004.

[118] M. Karin and F. R. Greten, "NF- $\kappa$ B: linking inflammation and immunity to cancer development and progression," Nature Reviews Immunology, vol. 5, no. 10, pp. 749-759, 2005. 


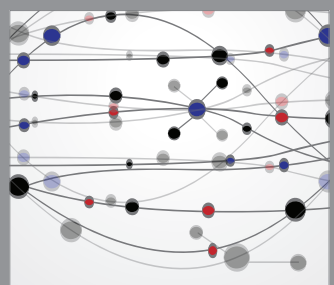

The Scientific World Journal
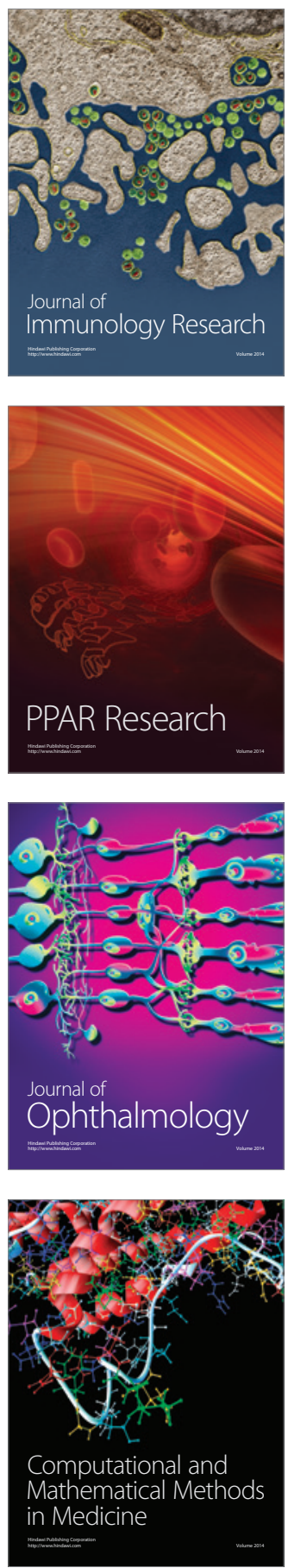

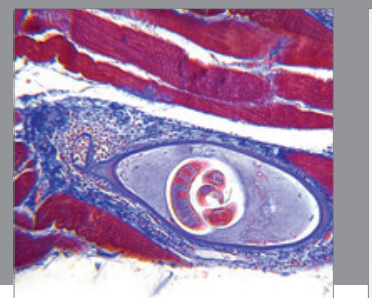

Gastroenterology

Research and Practice
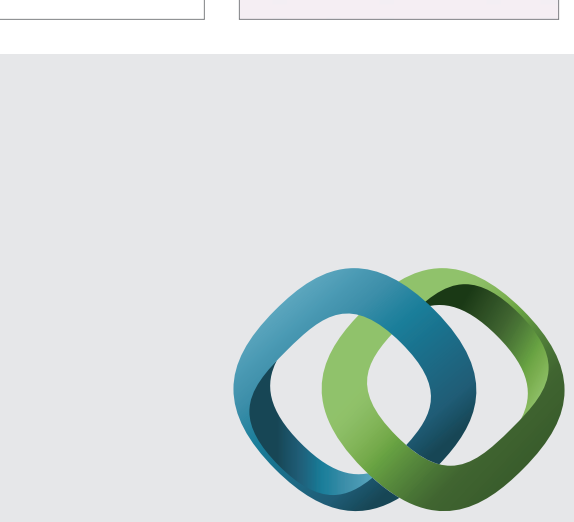

\section{Hindawi}

Submit your manuscripts at

http://www.hindawi.com
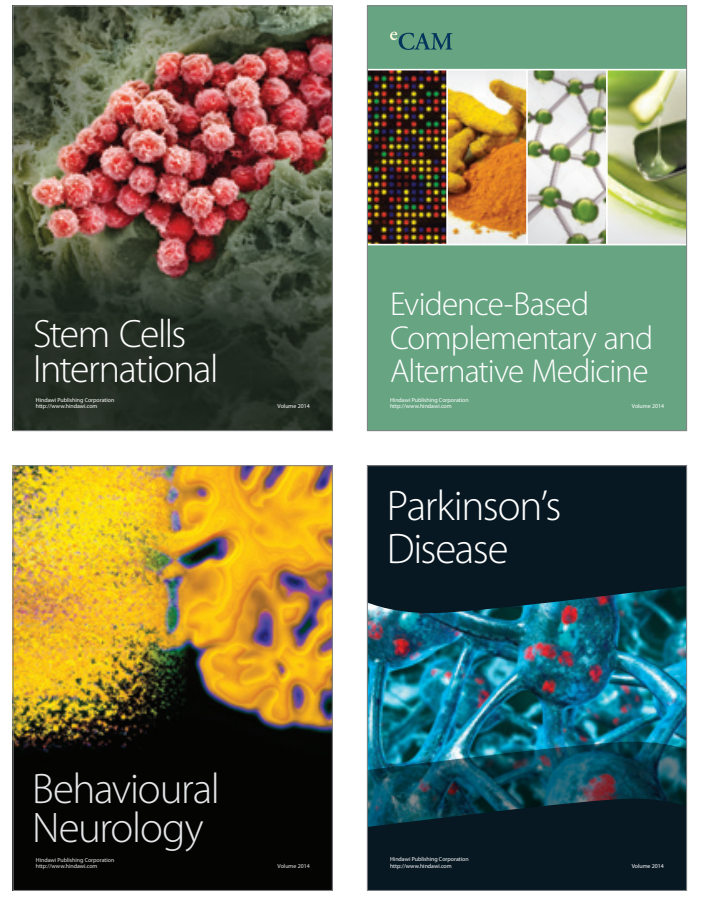
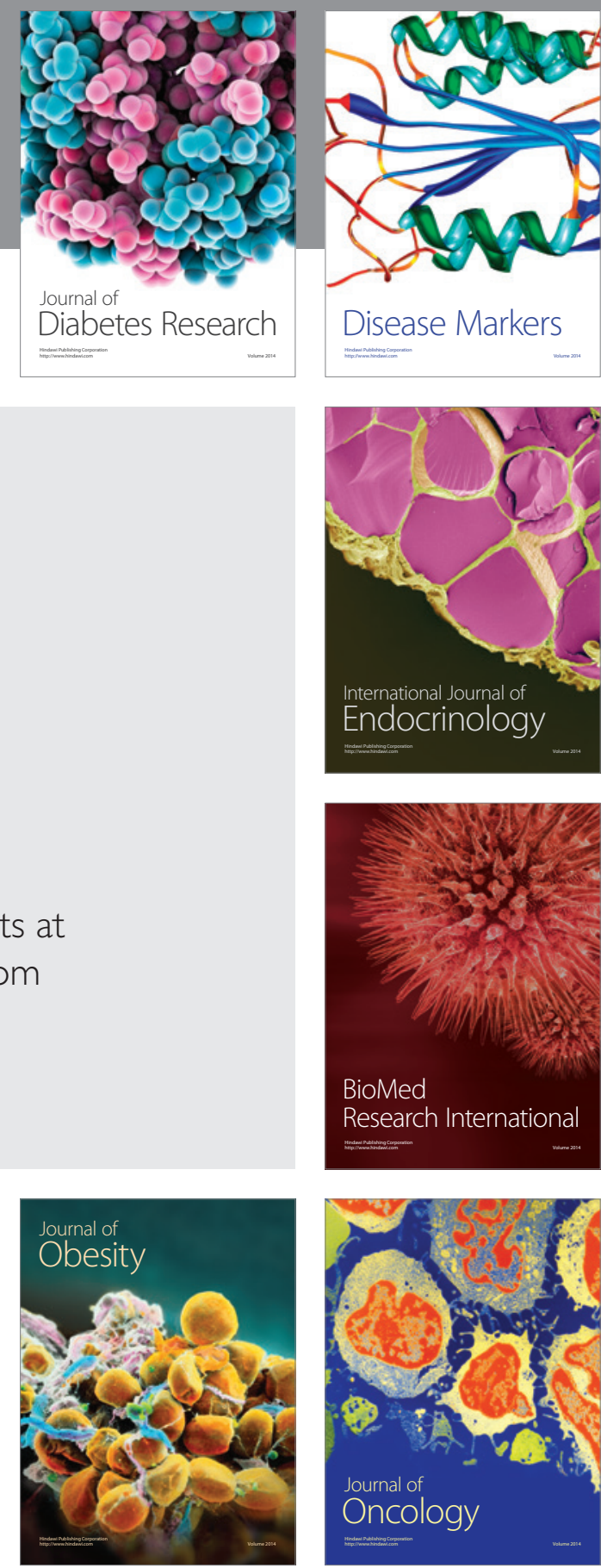

Disease Markers
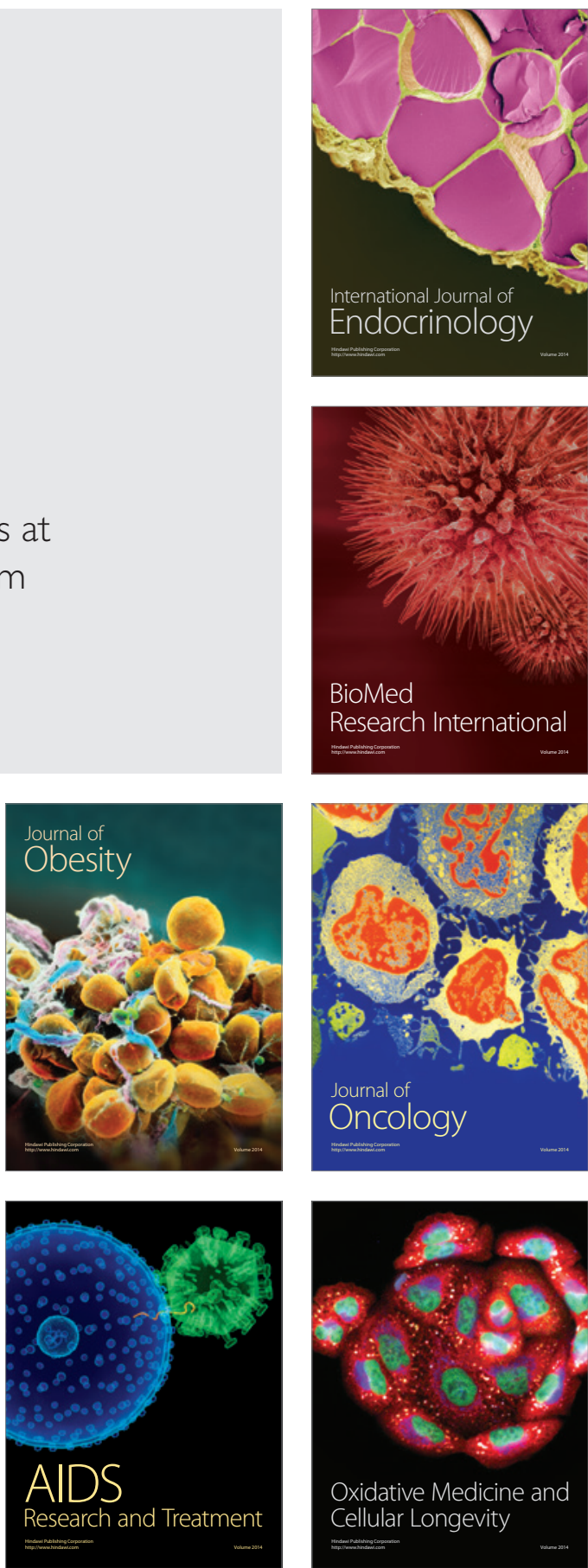